\title{
Historic flood marks and flood frequency analysis of the Danube River at Bratislava, Slovakia
}

\author{
Pavla Pekárová ${ }^{1 *}$, Dana Halmová ${ }^{1}$, Veronika Bačová Mitková ${ }^{1}$, \\ Pavol Miklánek ${ }^{1}$, Ján Pekár ${ }^{2}$, Peter Škoda ${ }^{3}$ \\ ${ }^{1}$ Institute of Hydrology SAS, Račianska 75, 83102 Bratislava, Slovakia. \\ ${ }^{2}$ Department of Applied Mathematics and Statistics, Faculty of Mathematics, Physics and Informatics, Comenius University, 84248 Brati- \\ slava, Slovakia. \\ ${ }^{3}$ Slovak Hydrometeorological Institute, Jeséniova 17, 83315 Bratislava, Slovakia. \\ *Corresponding author. Tel.: +4212 44259 404. E-mail: pekarova@uh.savba.sk
}

\begin{abstract}
In this paper we focused on the history of floods and extreme flood frequency analysis of the upper Danube River at Bratislava. Firstly, we briefly describe the flood marks found on the Danube River in the region of Bratislava, Slovakia, and provide an account of the floods' consequences. Secondly, we analyzed the annual maximum discharge series for the period 1876-2012, including the most recent flood of June 2013. Thirdly, we compare the values of $T$-year design discharge computed with and without incorporating the historic floods (floods of the years 1501, 1682, and 1787 into the 138-year series of annual discharge peaks). There are unfortunately only a few historic flood marks preserved in Bratislava, but there are very important and old marks in neighbouring Hainburg and other Austrian cities upstream to Passau. The calculated T-year maximum discharge of the Danube at Bratislava for the period 1876-2010 without and with historic flood values have been compared. Our analysis showed that without incorporating the historic floods from the years 1501,1682 , and 1787 the 1000-year discharge calculated only with data from the instrumented period 18762013 is $14,188 \mathrm{~m}^{3} \mathrm{~s}^{-1}$, and it is lower compared to the 1000-year discharge of $14,803 \mathrm{~m}^{3} \mathrm{~s}^{-1}$ when the three historic floods are included. In general, the $T$-year discharge is higher throughout the whole spectrum of $T$-year discharges $(10,20,50$, $100,200,500$-year discharge) when the three historic floods are included. Incorporating historic floods into a time series of maximum annual discharge seems to exert a significant effect on the estimates of low probability floods. This has important implications for flood managements and estimation of flood design discharge.
\end{abstract}

Keywords: Historic floods; Extreme flood peak; Flood hazard; Danube River; Bratislava.

\section{INTRODUCTION}

Baker (1993) in the Nature Journal entitled "Flood threat (after) learning from the past," pointed out the fact that every previous flood situation is invaluable experience for better estimation the following, the consequences of which would be through the implementation of measures to be less damaging". Determination of flood hazard is an important aspect yet a difficult task for hydrologic practice. Studying historic floods is important in order to reliably assess the statistical significance of floods that occur at the present or will occur in the future.

Historic data on floods is available from a variety of sources, including historical references, newspaper articles, and flood marks that can be found on buildings at key locations throughout flooded areas (Brazdil et al., 2006, 2010; Munzar et al., 2006; Neweklowsky, 2011; Rohr, 2005, 2007). The oldest known evidence of floods on the Danube goes back to 1012 A.D. Floods that occurred during the medieval times on the Austrian-Slovakian-Hungarian stretch of the river have been thoroughly described by Kiss (2011). Kiss (2011) identified several summer floods in the years 1235, 1316, 1402, 1414, 1432 , and 1490 . In general, the 15 th century was marked by a high occurrence of floods.

At Bratislava, the Danube in the past tended to form multiple branches after major floods. The river changed its course regularly. In the 13th century, one of these branches led along the old city walls, along the todays Hviezdoslav Square. During catastrophic floods, the Danube flooded even the old city center. The history of floods on the Danube at Bratislava has been previously examined by Horvathova (2003), who also used archived historical materials for flood description. From the 15 th century on, the oldest preserved evidence on floods at Bratislava refers to floods caused by ice jams, or ice barriers, damaging a bridge. These ice floods damaged seriously several buildings in the city. For instance, in 1426, Sigismond of Luxembourg, the Roman King of Bohemia and Hungary issued an order to repair the flood protecting banks along the river that had been damaged during the preceding flooding. Later, in 1430, Sigismond ordered to re-build the bridge across the Danube at Bratislava. The bridge was partially supported by a system of pillars laid on large boats (pontoons). Historic records mentioning bridge damages remain important pieces of flood evidence on this section of the river in the first half of the 15 th century. On March 20, 1439, a flood wave swept away one pontoon, and on July 30,1440, three bridge fields were swept away. It was in 1443 , on the Good Friday (Easter), when the whole bridge was damaged entirely (Horvathova, 2003).

The Danube floods which occurred after 1500 between Passau and Bratislava (Fig. 1) are generally well documented by flood marks. The flood marks are very important for estimation of the flood extent in comparison with recent high water levels, and for estimation of the extremality of the flood in historic time series. An example of such flood marks located in the vicinity of the river is shown in Fig. 2. As shown on the photographs, the highest flood after 1500 , reliably and authentically marked on the Danube River stretch between Passau to Bratislava, occurred in August 1501. Kresser (1957) estimated the peak discharge at Linz was to be up to $12,000 \mathrm{~m}^{3} \mathrm{~s}^{-1}$, and $14,000 \mathrm{~m}^{3} \mathrm{~s}^{-1}$ at Vienna. The aftermath of this "millennium flood" is reconstructed well in the historical annals: "carpenters 
and other craftsmen worked from August to December 1501, and again several months later in 1502, to repair the bridge" (Rohr, 2005). Numerous meadows and orchards along the river were destroyed during this flood. The administrative accounts (platbooks etc.) show that great changes in land ownerships happened after this flood, perhaps due to the fact that the former owners perished during the flood or just relocated to other regions. We were able to identify three summer floods (the floods of 1501, 1682, and 1787) in the available historical documents, when the discharge exceeded the arbitrary threshold value of 12,000 $\mathrm{m}^{3} \mathrm{~s}^{-1}$ at Bratislava (Kresser, 1957).

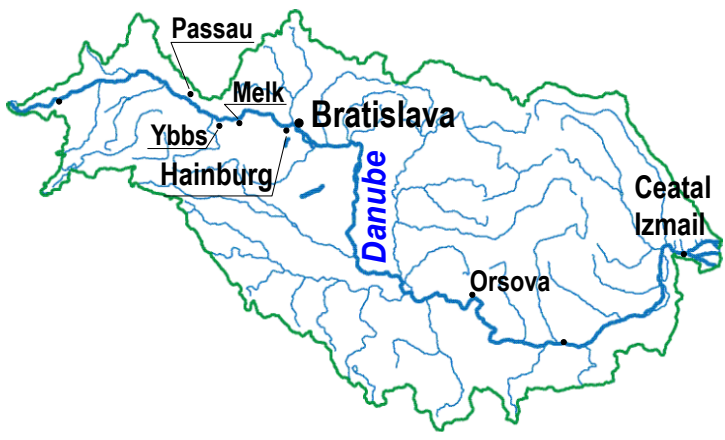

Fig. 1. Danube River basin, Bratislava station.

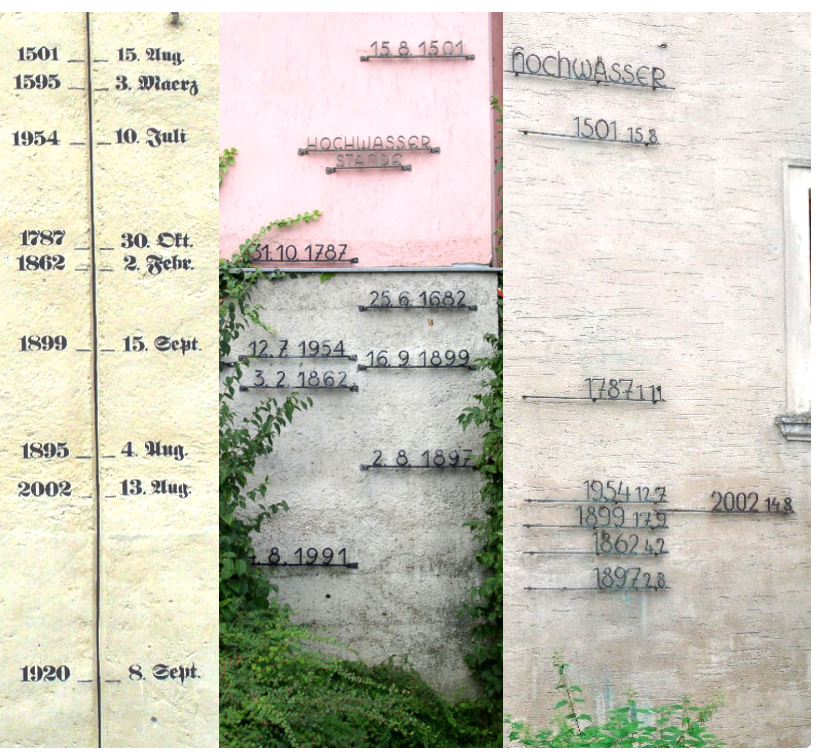

Fig. 2. Flood marks at Passau, Ybbs, and Melk (photo: Miklanek and Danecek, 2010).

\section{Flood marks at Bratislava}

Very few flood marks have been preserved in the area of Bratislava. Among those that are still preserved are the ice flood marks of 1809 and 1850, and the spring flood marks of 1895. A lot more flood marks can be found at the nearby city of Hainburg (Austria).

\section{The 1809 flood marks}

The 1809 ice flood belongs to the most extreme floods recorded by flood marks. It is because, due to its severity, the 1809 flood affected not only the communities in the DanubeKomarno river stretch, but also the communities in the lower section of the Morava River. At Komarno, on February 2, 1809, the Danube ice barrier breached the protective banks, and de- molished 400 houses. Pisut $(2002,2009)$ carried out a concise but detailed analysis of the 1809 flood at Bratislava. In 1809 (January, 29), the Danube breached the right bank and flooded the Bratislava city part - Petrzalka. Memorial flood mark on this flood can still be found in the flooded area (Fig. 3, point 1, Fig. 4). The most damaged parts on left bank of the Bratislava city were: Zuckermadel, Vydrica, (point 2), Gorkeho St., Jesenskeho St., and Laurinska St. (point 3), as well as Grösslingova St. A flood mark of this flood was located on building in the Lodna St. (point 4, Fig. 4). The flood mark of this flood inheres in Hainburg (Fig. 5).

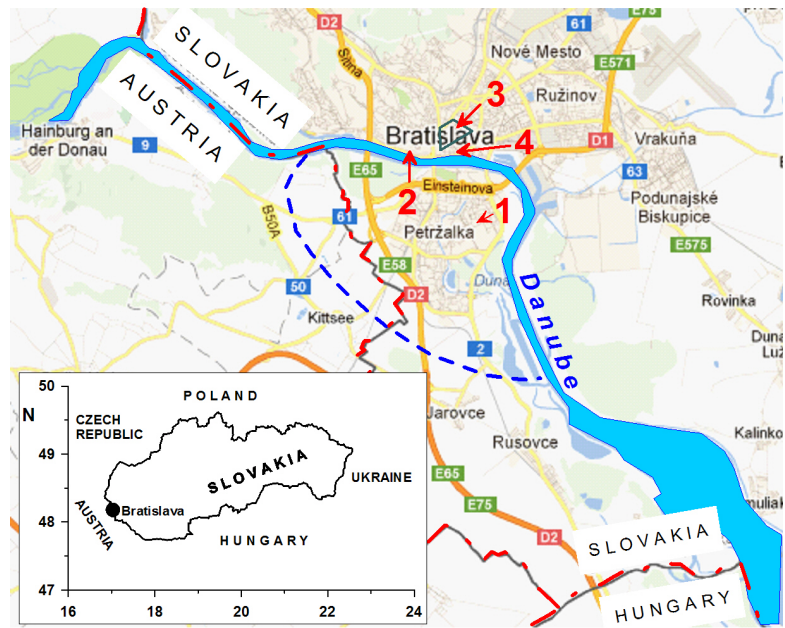

Fig. 3. Bratislava city, point 1 - Petrzalka city part; point 2 Zuckermandel, Vydrica; point 3 - old city; point 4 - Lodna street. Hainburg an der Donau, Austria.

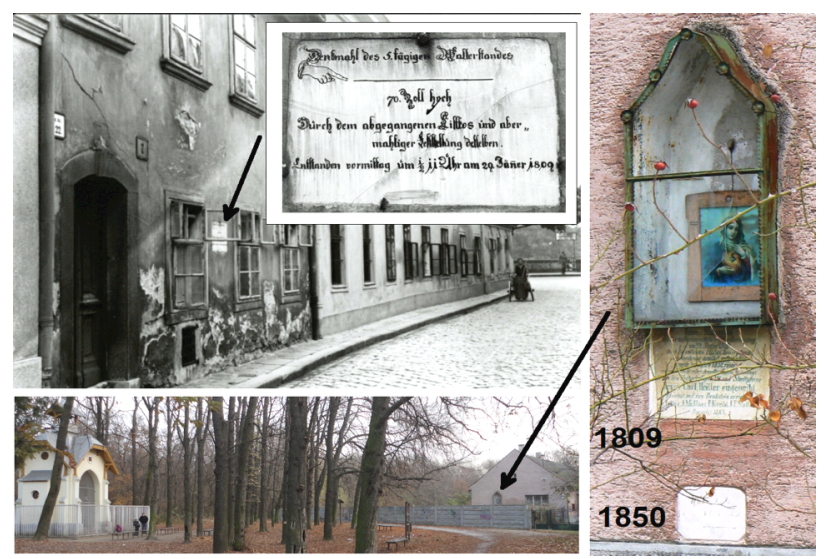

Fig. 4. Bratislava - Lodna St., 1809 flood mark (left up, photo from 1947 - Bratislava municipality archive); Petrzalka city part. (down, right), old historic Kotesova hunting keeper's lodge - 1809 and 1850 flood marks (photo: Pekarova, 2011).

\section{The 1850 flood marks}

During the flood of 1850 (February 5), the streets of Bratislava were under water again. Flood marks on the old buildings in the old town still show the height to which water reached during the past times. The water stage was then by nearly 200 cm higher than that of the 1954 flood. There are preserved three flood marks of this flood in the old city and one in Petrzalka suburb (Fig. 4) below the mark of 1809. The flood mark of 1850 in the city quarter called Zuckermandel is indicated on the photograph of the 1899 flood (Fig. 6). 


\section{The 1895 flood marks}

We found a flood mark from 1895 in the garden of the Holy Trinity church in Bratislava (Fig. 7). This flood can be characterized as a spring flood, which we date to the end of April, 1895. No severe damages due to this flood, upstream of Bratislava, have been reported (Melo et al., 2012; Pekarova et al., 2012). The 1895 Danube flood manifested its magnitude particularly on the lower river reach and on its tributaries. The flood became even the most severe flood observed during the period of instrumented observations. Its discharge was exceeded only much later, in the year 2006.

Further on, serious flood threads to Bratislava present the summer floods caused by intense eastward rainfall systems in the Danube basin. Such floods occurred in August 1501, July 1670, June 1682, and November 1787.

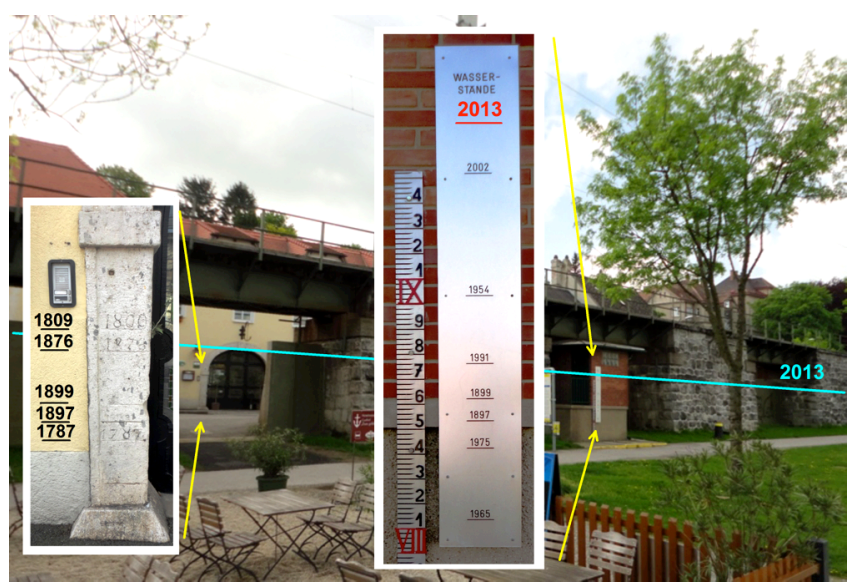

Fig. 5. Hainburg, Austria, water gauge station and historic flood marks (photo: Pekarova, 5. 5. 2013). Water stage June 6, 2013.

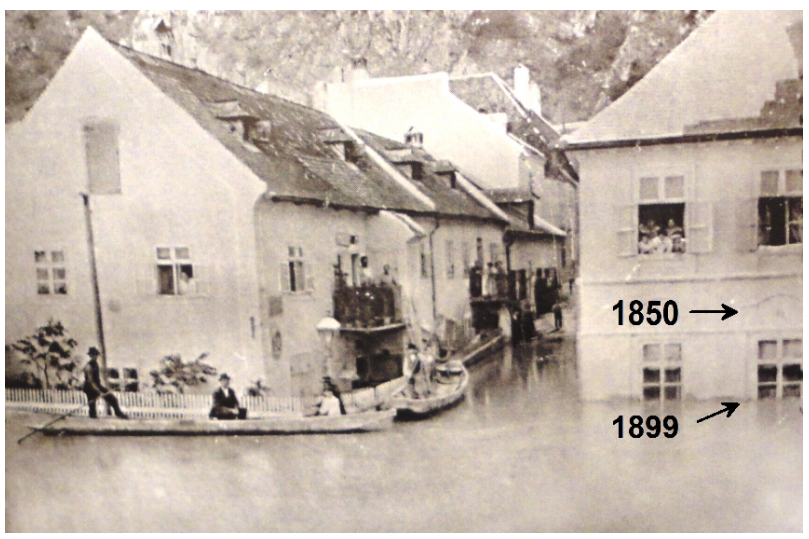

Fig. 6. Zuckermandel - Ballusova St. in 1899 - flood mark of the February $5^{\text {th }}, 1850$ flood, and water level of the 1899 flood (photo: adopted from the City Gallery of Bratislava).

\section{The August 1501 flood marks}

The oldest flood mark on the territory of Bratislava was on the Vydricka Brana (Vydrica Gate), and on the border between Zuckermandel and Vydrica (Bel, 1735). The Vydrica Gate was located on the old city's southwestern part. The Vydricka Gate was demolished in 1778 .

Mathias Bel gives in his Notitia also information about another 1516 Danube flood mark (Pekarova and Miklanek, 2012). It was located on the stone column with a cross sign, in the area between Zuckermandel and the Vydrica streets, close to the Danube in front of the royal arsenal building. Cico (2012) and Korabinsky (1786) describe this flood mark: In front of the warehouse gate in the $18^{\text {th }}$ century there stood an old statue of a bishop facing the river with a Latin inscription saying "Quod Istri vis hic diruit hoc rursus est exstructum, Anno 1670", on the rear side. The aforementioned column and the statue cannot be found anymore, perhaps because they were demolished by some of ice floods in the years 1775, 1809, or 1850 .

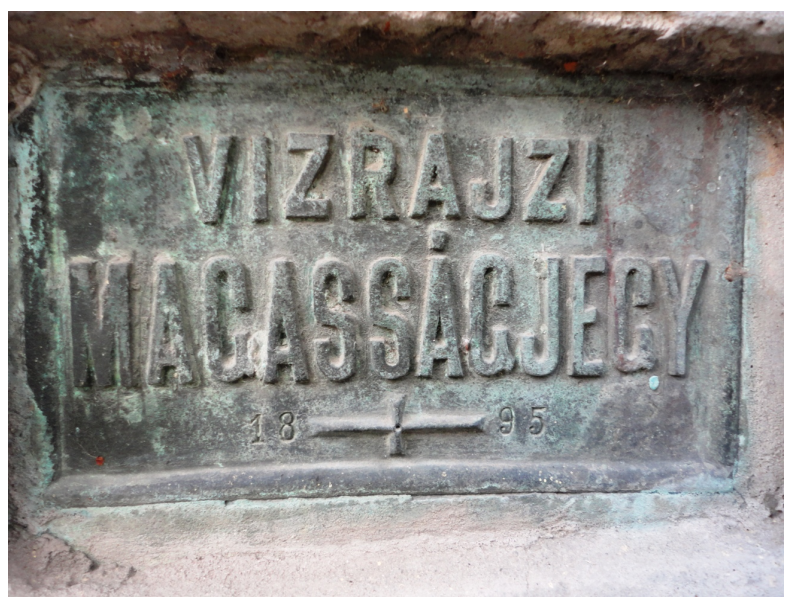

Fig. 7. The 1895 flood mark in the garden of Holy Trinity Church in Bratislava (photo: Miklanek, 2012).

\section{The November 1787 flood mark}

This was the most severe flood in the 18th century (1787), and it became to be known as the "All Saints' Flood". It occurred at the end of October and beginning of November. According to historical annals at the Austrian Hydrographic Service (Kresser, 1957), the peak discharge at Vienna reached $11,800 \mathrm{~m}^{3} \mathrm{~s}^{-1}$. Detailed description of this flood at Bratislava is given in Pisut (2011). The water level kept on rising since October 28, 1787. On November 1, 1787, the right protective bank broke along the Viennese road (built during the reign of the emperor Maria Theresa who commanded to build the banks a few years prior to this flood, in the years 1773-1774). Water flooded the whole Petrzalka town up to the community at Rusovce. A large lake of water formed here. Thanks to this Viennese road with a length of 406 meters, the water level at Bratislava ceased to rise before completely flooding the old city. Nevertheless, water flooded some of the courtyards and cellars of the inner city. The elevated water levels at Bratislava lasted from October 26, 1787 to November 6, 1787 (Preßburger Zeitung, 88, 89). The flood peaked at Bratislava on November 3,1787 , with a peak discharge exceeding the one estimated for Vienna at $11,800 \mathrm{~m}^{3} \mathrm{~s}^{-1}$ (Kresser, 1957). Without the spill caused by the breach of the Vienna Road protective "embankment", causing a partially flooding of the adjacent right-hand side area upstream of Bratislava, it is estimated that the flood peak in Bratislava would have reached $12,200 \mathrm{~m}^{3} \mathrm{~s}^{-1}$. A flood mark witnessing this flood is still preserved in Hainburg, Austria (Fig. 5). According to the local newspaper Preßburger Zeitung No. 88, the 1787 flood water level exceeded that of the large ice flood in 1775; visually marked on the military Water barracks (Pisut, 2011). A large erosion of the banks was observed during this flood, accompanied by an intense sediment transport through the river channel. 
ANNUAL MAXIMUM DISCHARGE SERIES OF THE DANUBE RIVER AT BRATISLAVA FOR THE PERIOD 1876-2013

First water stage measurements on the Danube River at Bratislava $\left(1,868.8 \mathrm{r} \mathrm{km}\right.$, catchment area $\left.131,338 \mathrm{~km}^{2}\right)$ were made in 1823. The gauge datum was at $131.08 \mathrm{~m} \mathrm{~J}$ (Adria system). After 1876 the average daily river stages were recorded in Hungarian yearbooks Vizallasok (1890). In 1942, the Bratislava gauge datum has been lowered by two meters, down to 129.08 m J (Adria system). After 1964, the gauge datum was determined at $128.43 \mathrm{~m} \mathrm{Bpv}$ (Baltic system). The first discharge observations at Bratislava, based on measurements of flow velocities, were available as early as 1882 (Mitkova et al., 2005; Pekarova et al., 2007a; Svoboda et al., 2000). Water stage measurements on the Danube River at Bratislava have been routinely processed since 1901 . In 2003, the staff of the SHMI (Slovak Hydrometeorological Institute) extended the average daily discharge series by adding data from 1891-1900. In our previous works we extended the average daily flow records by adding 15-years of daily water level observations
1876-1890 according to historic rating curve (Fig. 8a) (Pekarova et al., 2007a-b, 2008; Pekarova, 2009, 2010). Average daily discharge characteristics (1876-2010) are presented in Table 1 .

In Table 2, there are statistically processed the maximum annual discharge at Bratislava for the period after 1876. This time series is depicted in Fig. 9. The greatest floods in this river section during the instrumental observation period occurred in last quarter of the 19th century (1876-1900). Five floods with peak discharge exceeding $10,000 \mathrm{~m}^{3} \mathrm{~s}^{-1}$ occurred during the 1876-2013 period: once in June (2013), July (1954) and September (1899), and twice in August $(1897,2002)$. This data correspond to the data contained in Blöschl et al. (2013). In Table 3 we compared the peak water levels at Hainburg and Bratislava gauge, and discharge during these floods. By comparing the water level and discharge in the years 1899 and 2013 one can see that water level rises in this river reach at the similar discharge (Fig. 8b, Fig. 10). The reasons of this discrepancy can be attributed either to the altering river bed due to gradual sedimentation and narrowing of the Danube channel at Bratislava.

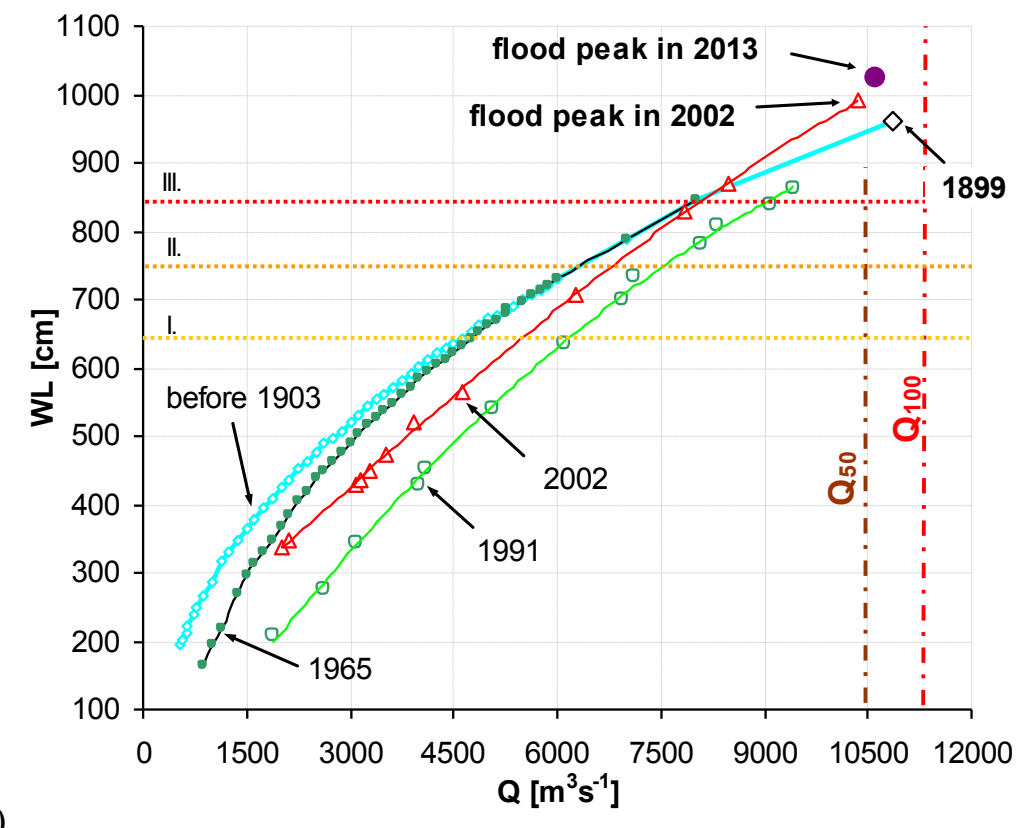

a)

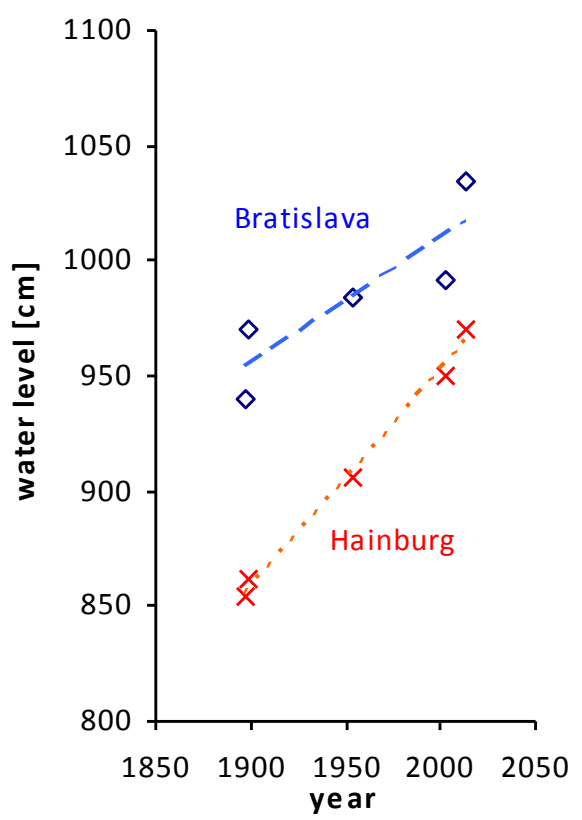

b)

Fig. 8a) Changes of the Danube rating curve at Bratislava gauge (related to the present gauge zero water level WL); b) Water levels at Hainburg and Bratislava gauge for floods with peak discharge exceeding 10,000 $\mathrm{m}^{3} \mathrm{~s}^{-1}$ at Bratislava during the 1876-2013 period.

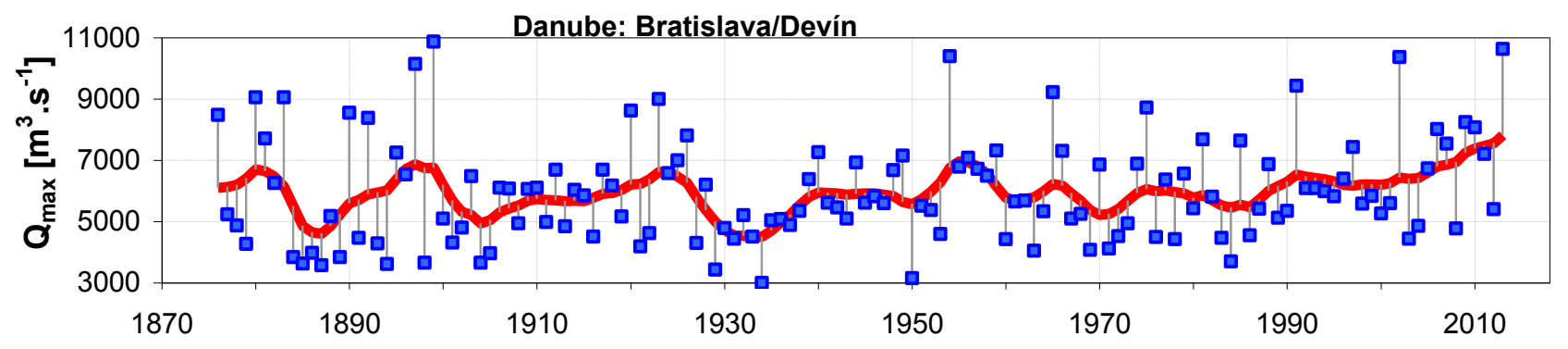

Fig. 9. Danube at Bratislava, instrumental period 1876-2013, annual maximum discharges (points) and annual discharge maxima 5-years moving averages (bold line). 
Pavla Pekárová, Dana Halmová, Veronika Bačová Mitková, Pavol Miklánek, Ján Pekár, Peter Škoda

Table 1. Average daily discharge characteristics of the Danube at Bratislava (1876-2010).

\begin{tabular}{lccccccc}
\hline & Mean & Min & Max & 330-day & 30 -day & $c_{s}$ & $c_{v}$ \\
\hline$Q\left(\mathrm{~m}^{3} \mathrm{~s}^{-1}\right)$ & 2,057 & 580 & 10,810 & 1,037 & 3,437 & 1.7 & 0.5 \\
$q\left(1 \mathrm{~s}^{-1} \mathrm{~km}^{-2}\right)$ & 15.7 & 4.4 & 82.3 & 7.9 & 26.2 & & \\
$R(\mathrm{~mm})$ & 493.9 & & & & & & \\
\hline
\end{tabular}

Table 2. Annual maximal discharge characteristics of the Danube at Bratislava.

\begin{tabular}{ccccccccc}
\hline & $\begin{array}{c}Q_{\max } \\
\left(\mathrm{m}^{3} \mathrm{~s}^{-1}\right)\end{array}$ & $\begin{array}{c}q_{\max } \\
\left(1 \mathrm{~s}^{-1} \mathrm{~km}^{-2}\right)\end{array}$ & $\begin{array}{c}\text { Min } \\
\left(\mathrm{m}^{3} \mathrm{~s}^{-1}\right)\end{array}$ & $\begin{array}{c}\text { Max } \\
\left(\mathrm{m}^{3} \mathrm{~s}^{-1}\right)\end{array}$ & $\begin{array}{c}c_{s} \\
(-)\end{array}$ & $\begin{array}{c}c_{v} \\
(-)\end{array}$ & $\begin{array}{c}\text { Med. } \\
\left(\mathrm{m}^{3} \mathrm{~s}^{-1}\right)\end{array}$ & Trend \\
\hline $1876-2013$ & 5,866 & 44.7 & 3,000 & 10,870 & 0.86 & 0.28 & 5,604 & 2.112 \\
\hline
\end{tabular}



Fig. 10. Water levels at Bratislava in $\mathrm{cm}$ (left), extreme floods. The gauge datum is determined at $128.43 \mathrm{~m}$ Bpv (Baltic system). Location of gauging station at Bratislava, (right, photo: Pekarova, 2012).

Table 3. Peak water level of the biggest instrumental floods at Hainburg (1883.9 river $\mathrm{km}$ ) and Bratislava (1868.8 river $\mathrm{km}$ ), discharge at Bratislava water gauge.

\begin{tabular}{cccc}
\hline Year & $\begin{array}{c}\text { Water level } \\
\text { Hainburg } \\
(\mathrm{cm})\end{array}$ & $\begin{array}{c}\text { Water level } \\
\text { Bratislava } \\
(\mathrm{cm})\end{array}$ & $\begin{array}{c}\text { Discharge } \\
\text { Bratislava } \\
\left(\mathrm{m}^{3} \mathrm{~s}^{-1}\right)\end{array}$ \\
\hline 1897 & 854 & 940 & 10,140 \\
1899 & 862 & 970 & 10,870 \\
1954 & 906 & 984 & 10,400 \\
2002 & 940 & 991 & 10,310 \\
2013 & 970 & 1,034 & 10,640 \\
\hline
\end{tabular}

\section{T-YEAR DESIGN DISCHARGE COMPUTED WITH AND WITHOUT INCORPORATING THE HISTORIC FLOODS}

In general, severity of every flood, with respect to its peak flow, is expressed as the probability of its occurrence or exceedance (Blöschl and Merz, 2008). Based on the historical references, we set up a series of historically significant floods (since 1501) on the Danube upstream of Bratislava (Fig. 11). In this river section, there are about ten summer floods known to have occurred before 1876 . We used the maximum discharge time series $Q_{\max }$ from the period of instrumented measurements 
on the Danube for the period 1876-2013, including three historic floods (from the years 1501, 1682, and 1787).

Firstly, we needed to choose the appropriate type of the theoretical probability distribution curve. We tested several models to achieve a good fit to the flood-discharge data. The choice of the distribution curves has substantial effect on the estimation of the $T$-year discharge, particularly for high return periods. For example, the 1000-year discharge according to log-normal distribution on the Danube River at Bratislava station is $13,977 \mathrm{~m}^{3} \mathrm{~s}^{-1}$, and according to log-Pearson III. type distribution it is $14,188 \mathrm{~m}^{3} \mathrm{~s}^{-1}$. We recommend the log-Pearson type III (LP3) distribution using in flood frequency investigations. In the next step, we included the historic floods from the years 1501,1682 , and 1787 into the 138-year series of annual discharge peaks (Fig. 12). The calculated $T$-year maximum discharge of the Danube at Bratislava for the period 1876-2013 without and with estimates of historic flood discharges are listed in Table $4 \mathrm{a}-\mathrm{b}$. A consistent increase in the $T$-year discharge can be seen when the three floods from the preinstrumental period are included.

\section{DISCUSSION AND CONCLUSIONS}

The EU Flood Directive requires from the EU member states to elaborate the flood threat and flood risk maps, for floods of a very small exceedance probability, for return periods $T$ : $500-$ 1000 years. For a correct estimation of extreme flood peaks it is necessary to back up the statistically processed data series with as much historic data on discharge as possible. Having such data improves the quality and accuracy of flood hazard mapping, flood insurance studies, and flood risk analysis. Understanding the risks posed by future flooding can only begin by understanding flood events that have already occurred. It is challenging to use flood marks in order to predict actual flood discharges due to frequent, mainly anthropogenic, modification of channels and nearby floodplains during historic times influencing the cross-section area and the hydraulic roughness. In order to overcome this problem, some authors developed simple approaches to estimate peak discharges of historic floods (Elleder et al., 2013).

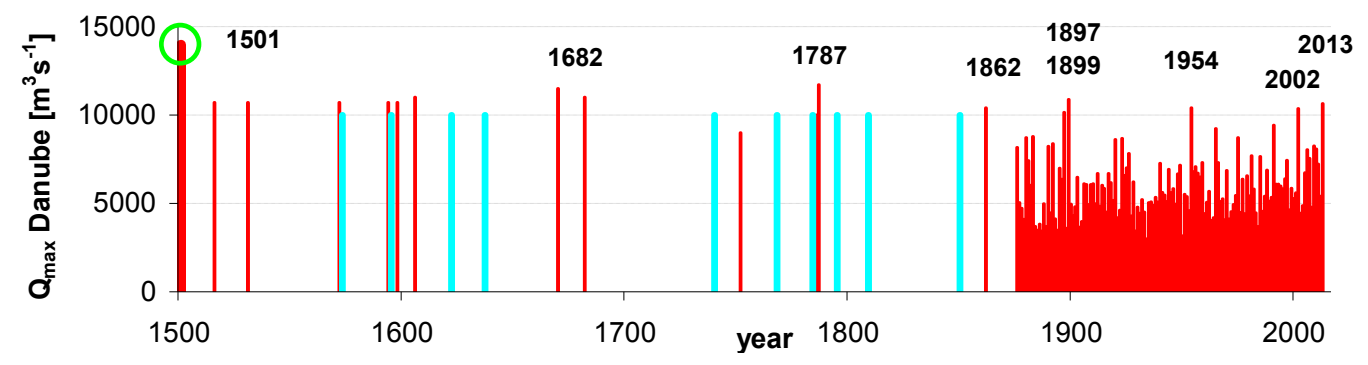

Fig. 11. Historic Danube floods in river section Kienstock - Bratislava since 1500 up to 1876 (dark columns - summer floods, light columns - winter floods); since 1876 - the observed annual peaks $Q_{\max }$ at Bratislava station.
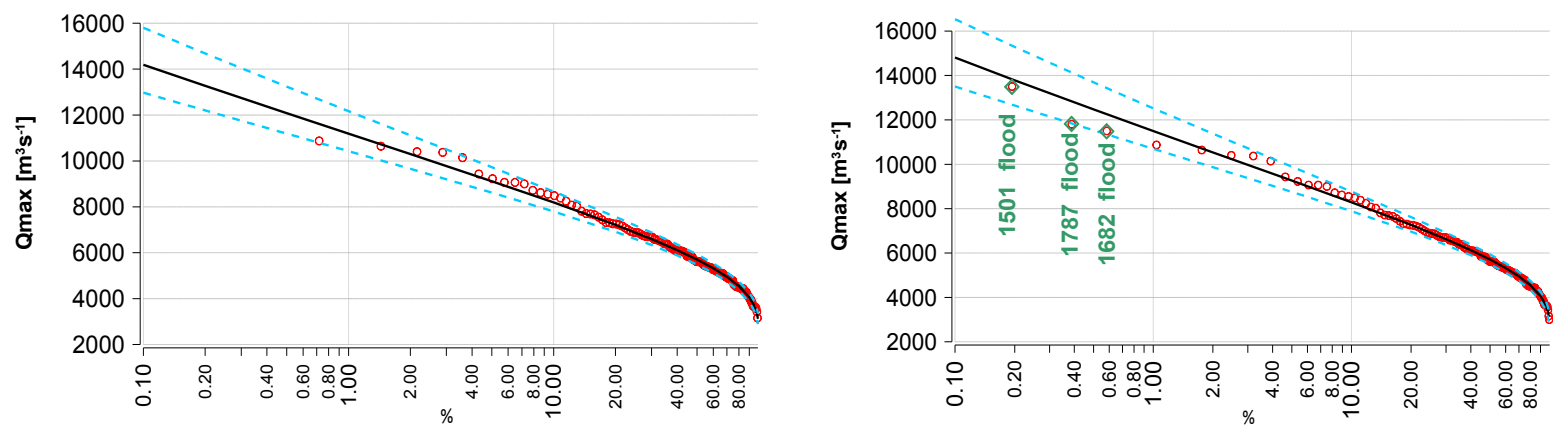

Fig. 12. Empirical and theoretical - log-Pearson type III distribution curve of the annual maximum discharge without and with historic floods, $5 \%$ and $95 \%$ confidence limits, Danube: Bratislava.

Table 4a. $T$-year peak flow $Q_{\max }\left(\mathrm{m}^{3} \mathrm{~s}^{-1}\right)$, log-Pearson type III distribution; $C L$ - confidence limits; Danube at Bratislava, 1876-2013, without historic floods.

\begin{tabular}{lccccccc}
\hline$T$ in years & 1000 & 500 & 200 & 100 & 50 & 20 & 10 \\
\hline$Q\left(\mathrm{~m}^{3} \mathrm{~s}^{-1}\right)$ & 14,188 & 13,271 & 12,079 & 11,187 & 10,297 & 9,112 & 8,189 \\
$95 \% C L\left(\mathrm{~m}^{3} \mathrm{~s}^{-1}\right)$ & 12,971 & 12,199 & 11,187 & 10,424 & 9,655 & 8,618 & 7,798 \\
$5 \% C L\left(\mathrm{~m}^{3} \mathrm{~s}^{-1}\right)$ & 15,801 & 14,680 & 13,236 & 12,166 & 11,111 & 9,723 & 8,662 \\
\hline
\end{tabular}

Table 4b. $T$-year peak flow $Q_{\max }\left(\mathrm{m}^{3} \mathrm{~s}^{-1}\right)$, log-Pearson type III distribution; CL - confidence limits; the Danube at Bratislava, 1876-2013, with historical floods.

\begin{tabular}{lccccccc}
\hline$T$ in years & 1000 & 500 & 200 & 100 & 50 & 20 & 10 \\
\hline$Q\left(\mathrm{~m}^{3} \mathrm{~s}^{-1}\right)$ & 14,803 & 13,783 & 12,468 & 11,494 & 10,532 & 9,262 & 8,287 \\
$95 \% C L\left(\mathrm{~m}^{3} \mathrm{~s}^{-1}\right)$ & 13,500 & 12,642 & 11,528 & 10,695 & 9,864 & 8,754 & 7,887 \\
$5 \% C L\left(\mathrm{~m}^{3} \mathrm{~s}^{-1}\right)$ & 16,533 & 15,283 & 13,688 & 12,519 & 11,376 & 9,890 & 8,768 \\
\hline
\end{tabular}


Our analysis showed that without incorporating the historic floods from the years 1501, 1682, and 1787 into the dataset of discharge data covering the instrumental period (1876-2013), the 1000-year discharge calculated only with data from the instrumented period is $14,188 \mathrm{~m}^{3} \mathrm{~s}^{-1}$ (from $12,971 \mathrm{~m}^{3} \mathrm{~s}^{-1}$ to $15,801 \mathrm{~m} \mathrm{~s}^{3} \mathrm{~s}^{-1}$ ) compared to the 1000-year discharge of 14,803 $\mathrm{m}^{3} \mathrm{~s}^{-1}$ (from $13,500 \mathrm{~m}^{3} \mathrm{~s}^{-1}$ to $16,533 \mathrm{~m}^{3} \mathrm{~s}^{-1}$ ) when the three historical floods exceeding an arbitrarily chosen threshold of $11,000 \mathrm{~m}^{3} \mathrm{~s}^{-1}$ are included. In general, the $T$-year discharge is higher throughout the whole spectrum of $T$-year discharges $(10$, $20,50,100,200,500$-year discharge) when the three historic floods are included. Based on our results, we subscribe to the conclusions of Gaal et al. (2010), i.e. incorporating historic floods into a time series of maximum annual discharge significantly improves estimation of low probability floods (500 1000-year floods).

For a correct estimation of extreme flood peaks it is necessary to back up the statistically processed data series with as much historical information as possible. In this study, we present an example of such $T$-years flood peaks for the Bratislava gauging station.

Our evaluations consistently reveal that the LP3 threeparameter probabilistic model provides a good approximation to flood-flow data in the Upper-Central Danube River stretch.

It remains an interesting avenue for future research to include historic flood discharges at other gauging stations on the Danube and many other gauging stations located on other rivers of Slovakia.

Acknowledgement. This work was supported by the Science and Technology Assistance Agency under contract No. APVT0015-10 and project MVTS "Flood regime of rivers in the Danube river basin" during the "the Centre of excellence for integrated flood protection of land" (ITMS 26240120004) project implementation supported by the Research \& Development Operational Programme funded by the ERDF.

\section{REFERENCES}

Baker, V.R., 1993. Flood hazards-Learning from the past. Nature, 361, 402-403.

Bel, M., 1735. Notitia Hvngariae Novae HistoricoGeographica: Divisa In Partes Qvatvor, Qvarvm Prima, Hvngariam Cis-Danvbianam; Altera, Trans-Danubianam; Tertia, Cis-Tibiscanam; Qvarta, Trans-Tibiscanam: Vniuersim XLVIII. Tomus Primus.

Blöschl, G., Merz, R., 2008. Bestimmung von Bemessungshochwässern Gegebener Jährlichkeit - Aspekte Einer Zeitgemäßen Strategie (Estimating design floods of a given return period - Facets of a contemporary strategy). WasserWirtschaft, 98(11), 12-18.

Blöschl, G., Nester, T., Komma, J., Parajka, J., Perdigão, R.A.P., 2013. The June 2013 flood in the Upper Danube basin, and comparisons with the 2002, 1954 and 1899 floods. Hydrol. Earth Syst. Sci. Discuss., 10, 9533-9573.

Brazdil, R., Demaree, G.R., Deutsch, M., Garnier, E., Kiss, A., Luterbacher, J., Macdonald, N., Rohr, C., Dobrovolny, P., Kolar, P., Chroma, K., 2010. European floods during the winter 1783/1784: Scenarios of an extreme event during the 'Little Ice Age'. Theoretical and Applied Climatology, 100(1), 163-189.

Brazdil, R., Kundzevic, Z.W., Benito, G., 2006. Historical hydrology for studying flood risk in Europe. Hydrological
Sciences Journal, 51(5), http://dx.doi.org/10.1623/hysj.51.5.739

Cico, M., 2012. Personal communication. Manuscript of the monograph on Bratislava`s Podhradie.

Directive 2007/60/EC of the European Parliament and of the Council of 23 October 2007 on the assessment and management of flood risks.

Elleder, L., Herget, J., Roggenkamp, T., Nießen, A., 2013. Historic floods in the city of Prague - a reconstruction of peak discharges for 1481-1825 based on documentary sources. Hydrology Research, 44(2), 202-214.

Gaal, L., Szolgay, J., Kohnova, S., Hlavcova, K., Viglione, A., 2010. Inclusion of historical information in flood frequency analysis using a Bayesian MCMC technique: A case study for the power dam Orlik, Czech Republic. Contributions to Geophysics and Geodesy, 40(2), 121-147.

Horvathova, B., 2003. Flood is not only the high water. (Povodeň to nie je iba vel'ká voda.) VEDA, Bratislava, 232 pp. (In Slovak.)

Kiss, A., 2011. Floods and long-term water-level changes in medieval Hungary. PhD Thesis, CEU, Szeged-Budapest, 323 pp.

Korabinsky, J.M., 1786. Geographisch-historisches und Produkten Lexikon von Ungarn. Pressburg, 858 pp.

Kresser, W., 1957. Floods of the Danube. (Die Hochwässer der Donau.) Springer Verlag, Wien, 95 pp. (In German.)

Melo, M., Pekarova, P., Dujsikova, C., Melova, K., 2012. The Danube flood in year 1895. Part I.: In historical documents. Acta Hydrologica Slovaca, 13, 2, 271-279. (In Slovak.)

Merz, R., Blöschl, G., 2008a. Flood frequency hydrology: 1. Temporal, spatial, and causal expansion of information. Water Resources Research, 44, W08432.

Merz, R., Blöschl, G., 2008b. Flood frequency hydrology: 2. Combining data evidence. Water Resources Research, 44, W08433.

Mitkova, V., Pekarova, P., Miklanek, P., Pekar, J. 2005. Analysis of flood propagation changes in the Kienstock-Bratislava reach of the Danube River. Hydrological Sciences Journal, $50,4,655-668$.

Munzar, J., Deutsch, M., Elleder, L., Ondracek, S., Kallabova, E., Hradek, M., 2006. Historical floods in Central Europe and their documentation by means of floodmarks and other epigraphical monuments. Morav. Geograph. Rep., 14, 26-44.

Neweklowsky, E., 2011. The Danube at Linz and their regulation. (Die Donau bei Linz und ihre Regelung.) In: Naturkundliches Jahrbuch der Stadt Linz, http://81.10.184.26:9001/pdf/NKJB_1_0171-0226.pdf (In German.)

Pekarova, P., Pacl, J., Skoda, P., Miklanek, P., 2007a. Supplementation of average daily discharge data of the Danube River in Bratislava with the historical period 1876-1890. Acta Hydrologica Slovaca. 8, 1, 3-11. (In Slovak.)

Pekarova, P., Miklanek, P., Pekar, J., 2007b. Long-term Danube monthly discharge prognosis for the Bratislava station using stochastic models. Meteorologický časopis. 10, 2, 211-218.

Pekarova, P., 2009. Multiannual runoff variability in the upper Danube region. Doctor of Science Thesis, Bratislava, IH SAS, 151 pp. $<$ Http://147.213.145.2/pekarova $>$

Pekarova, P., Onderka, M., Pekar, J., Miklanek, P., Halmova, D., Skoda, P., Bacova Mitkova, V., 2008. Hydrologic Scenarios for the Danube River at Bratislava. Ostrava, KEY Publishing, 159 pp. 
Pekarova, P., 2010. Flood regime of rivers in the Danube River basin. In: Hydrological Days 2010, Hradec Králové, 95-101.

Pekarova, P., Miklanek, P., 2012. Historical flood marks in Bratislava in the area of the Vydrica Gate and Zuckermandel. In: Proc: Influence of water structures on formation and protection of the territory, Slovak University of Technology, Bratislava, 114-127. (In Slovak.)

Pekarova, P., Miklanek, P., Pekar, J., Melo, M., 2012. The Danube flood in year 1895. Part II.: In instrumental discharge data. Acta Hydrologica Slovaca, 13, 2, 280-288. (In Slovak.)

Pisut, P., 2002. Channel evolution of the pre-channelized Danube River in Bratislava, Slovakia (1712-1886) Earth Surf. Process. Landforms, 27, 369-390.

Pisut, P., 2009. Cartographic evidence of the disastrous ice flood of 1809 and its aftermath (Danube River, Slovakia). Geophysical Research Abstracts, 11, EGU2009-9201.
Pisut, P., 2011. The 1787 flood of the River Danube in Bratislava. Geographical J., 63, 87-109. (In Slovak).

Preßburger Zeitung, (88), November, 3, 1787.

Preßburger Zeitung, (89), November, 7, 1787.

Rohr, C., 2005. The Danube floods and their human response and perception (14th to 17 th C). History of Meteorology, 2, 71-86.

Rohr, C., 2007. Extreme Naturereignisse im Ostalpenraum. Naturerfahrung im Spätmittelalter und am Beginn der Neuzeit, Böhlau-Verlag GmbH, 640 pp.

Svoboda, A., Pekarova, P. Miklanek, P., 2000. Flood Hydrology of Danube between Devin and Nagymaros. Bratislava, UH SAV, SVH, 96 pp.

Vizallasok, 1890. Vizallasok a Dunaban. Hornyanszky Viktor Könyvnyomdaja, Budapest.

Received 13 December 2012 Accepted 2 October 2013 